\title{
Distribution of absorbed heat in luminescent solar concentrator lightguides and effect of temperatures of mounted photovoltaic cells
}

\section{Citation for published version (APA):}

Rajkumar, V. A., Weijers, C., \& Debije, M. G. (2015). Distribution of absorbed heat in luminescent solar concentrator lightguides and effect of temperatures of mounted photovoltaic cells. Renewable Energy, 80, 308315. https://doi.org/10.1016/j.renene.2015.02.003

\section{Document license:}

TAVERNE

DOI:

10.1016/j.renene.2015.02.003

Document status and date:

Published: 01/01/2015

\section{Document Version:}

Publisher's PDF, also known as Version of Record (includes final page, issue and volume numbers)

\section{Please check the document version of this publication:}

- A submitted manuscript is the version of the article upon submission and before peer-review. There can be important differences between the submitted version and the official published version of record. People interested in the research are advised to contact the author for the final version of the publication, or visit the $\mathrm{DOI}$ to the publisher's website.

- The final author version and the galley proof are versions of the publication after peer review.

- The final published version features the final layout of the paper including the volume, issue and page numbers.

Link to publication

\footnotetext{
General rights

- You may freely distribute the URL identifying the publication in the public portal. follow below link for the End User Agreement:

www.tue.nl/taverne

\section{Take down policy}

If you believe that this document breaches copyright please contact us at:

openaccess@tue.nl

providing details and we will investigate your claim.
}

Copyright and moral rights for the publications made accessible in the public portal are retained by the authors and/or other copyright owners and it is a condition of accessing publications that users recognise and abide by the legal requirements associated with these rights.

- Users may download and print one copy of any publication from the public portal for the purpose of private study or research.

- You may not further distribute the material or use it for any profit-making activity or commercial gain

If the publication is distributed under the terms of Article 25fa of the Dutch Copyright Act, indicated by the "Taverne" license above, please 


\title{
Distribution of absorbed heat in luminescent solar concentrator lightguides and effect on temperatures of mounted photovoltaic cells
}

\author{
Vikram A. Rajkumar ${ }^{\text {a }}$, Cees Weijers ${ }^{\mathrm{b}}$, Michael G. Debije ${ }^{\mathrm{c}, *}$ \\ a Dept. Mechanical Engineering, Eindhoven University of Technology, 5600 MB Eindhoven, The Netherlands \\ b Polymer Technology Group Eindhoven BV, De Lismortel 31, 5612 AR Eindhoven, The Netherlands \\ ${ }^{\mathrm{C}}$ Dept. Chemical Engineering \& Chemistry, Eindhoven University of Technology, $5600 \mathrm{MB}$ Eindhoven, The Netherlands
}

\section{A R T I C L E I N F O}

\section{Article history:}

Received 25 February 2014

Accepted 3 February 2015

Available online

\section{Keywords:}

Luminescent solar concentrator

Polymer lightguide

Fluorescence

Heat

Photovoltaic

\begin{abstract}
A B S T R A C T
Polymer plates containing fluorescent dyes with photovoltaic cells attached to one or more edges have the potential to be used for solar light collection in the built environment. The heating of the polymer plates and the resulting effects this may have on the operating temperatures of the attached photovoltaic cells and the integrity of the cells are studied. The results indicate that the luminescent solar concentrator under a solar simulator will allow the edge attached photovoltaic cells to operate up to $10{ }^{\circ} \mathrm{C}$ cooler compared to cells experiencing direct solar exposure because of the avoidance of infrared light. We also demonstrate the importance of correct adhesive to avoid rupture of the attached cell.
\end{abstract}

() 2015 Elsevier Ltd. All rights reserved.

\section{Introduction}

The luminescent solar concentrator (or LSC) has been suggested as being an electricity generator from sunlight particularly wellsuited for use in the urban setting [1-4]. Essentially, the LSC is a plastic lightguide filled with fluorescent dye molecules, or is a clear polymer lightguide topped by a thin layer of polymer doped with the fluorescent dye. The LSC collects a fraction of the incident solar light via absorption by the fluorescent dye. This light is then either re-emitted at a longer wavelength by the fluorophore or lost as heat to the lightguide environment. The re-emitted light will either be directed in such a way as to be outside the 'capture cone' of the polymer lightguide and escape through the top or bottom surface, or trapped via total internal reflection within the plate [3]. Barring a re-absorption event of the emitted light by a subsequent dye molecule owing to the limited Stokes shift of the dyes or absorption by the lightguide material, the emission light will exit the edges of the LSC, where one can place small, high efficiency photovoltaic (PV) cells to convert the emitted light into electricity [5-7]. The LSC could be made in many different colors, could be molded into different shapes and cut to almost any size, and functions well

\footnotetext{
* Corresponding author.

E-mail address: m.g.debije@tue.nl (M.G. Debije).
}

under both direct and indirect sunlight. Fig. 1 gives a graphical representation of the functionality of the device.

The deployment of PV panels has been the subject of considerable research [8,9] and much is known regarding the thermal effects on PV panel performance. PV cells in solar panel arrays absorb light over a wide energy range of incident photons, but only require a specific energy to generate the electron in the external circuit. For a typical crystalline silicon PV, the upper sensitivity boundary of a solar cell is $\lambda_{\max }=1110 \mathrm{~nm}$ [10], which corresponds to the band gap in silicon at room temperature, so absorbed wavelengths beyond $1100 \mathrm{~nm}$ do not generate any electrical current and only serve to warm the device. Likewise, the extra energy contained in a high energy photon beyond that needed to generate the charge carrying species in the cell also goes into thermal energy. This heat adversely influences the performance of the solar cell [11-15]. A general rule of thumb is the efficiency of a crystalline silicon solar cell decreases $0.5 \%$ for every $1{ }^{\circ} \mathrm{C}$ above $25^{\circ} \mathrm{C}[16,17]$. Given a solar cell can reach temperatures well in excess of $50{ }^{\circ} \mathrm{C}$ on a sunny day $[11,18,19]$, this can result in a significant performance loss. Several methods have been proposed to maintain a cooler temperature for the PV cell, including coupling to heat spreaders, natural and forced ventilation, water cooling, heat pipe cooling, and phase change materials, among others (see Ref. [17] for a recent review).

While considerable literature exists detailing the effects of heating on PV cells and panels and a number of solutions have 


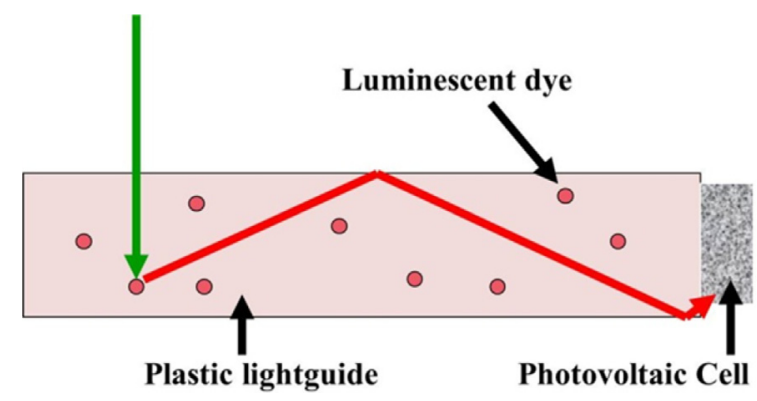

Fig. 1. The luminescent solar concentrator. Incident light (green arrow) is absorbed by embedded luminescent dye and re-emitted at a longer wavelength (red arrow). A fraction of the light reaches the lightguide edge where it may be converted into electrical current via an attached photovoltaic cell. (For interpretation of the references to color in this figure legend, the reader is referred to the web version of this article.)

been generated, there is little known as to the effects of light exposure and the heat distribution in LSC devices. As a direct consequence of heating of the LSC, the device will undergo expansion, and insight into the effects of the mismatched thermal expansion coefficients of the polymeric plate and predominantly inorganic photovoltaic attached to the side have not been adequately discussed in the literature. As the LSC becomes more viable for deployment, it becomes increasingly necessary to understand how they might perform under realistic external conditions. The fluorescent dyes embedded in the LSC do not absorb over the entire solar spectrum. Rather, they typically absorb wavelengths in the visible range only, the other incident wavelengths (beyond $\sim 700 \mathrm{~nm}$ ) pass through the lightguide. The fluorescent dyes typically have high quantum yields (>90\%) [20], meaning most of the absorbed energy is reemitted into a relatively narrow, red-shifted bandwidth of emission wavelengths, and it is this restricted range of wavelengths that exit the lightguide edge and enter the PV. The attached PV, therefore, will not be directly exposed to higher-energy photons which cause unnecessary heating, nor to infrared photons which are beyond the bandgap of the cell and do not contribute at all towards electrical generation as they are in a typical PV panel. It has therefore been assumed that the solar cells on the edges of an LSC will run 'cooler' than when used directly facing the sun, which in turn should maintain their performance at a higher level, but to date this has not been experimentally verified.

In this study, we perform the first measurements of the temperature profiles across the LSC device and monitor the flow of heat within the lightguide. We also monitor the temperature of attached PV cells and compare to temperatures reached when directly exposed to the light source and when attached to the lightguide edges. Finally, we study the effect of different glues on the integrity of the attached photovoltaic cells. We confirm the reduced temperatures for edge-mounted rather than rear- or surface-mounted PV cells (up to $\sim 10{ }^{\circ} \mathrm{C}$ ) and demonstrate the importance of selecting the correct glue for cell attachment to the lightguide edges, as incorrect choice can result in the breakage of the PV due to unmatched thermal expansions.

\section{Experimental methods}

This work employed $17.5 \times 17.5 \times 0.6 \mathrm{~cm}^{3}$ injection molded (poly)carbonate plates generously supplied by Sabic IP doped with either 115 ppm Lumogen Red 305 (BASF) [21] or 75 ppm perylene perinone [22] fluorescent dye, as well as non-doped plates, and a $60 \times 40 \times 2 \mathrm{~cm}^{3}$ cast PMMA plate containing Red 305 from Evonik.
Surface heat emission was monitored for the LSCs by a Thermacam T400 thermal camera (FLIR Systems). To measure the temperature of PV cells attached to a (poly)carbonate lightguide filled with Red 305 dye, a thermocouple was adhered to the surface of the $3.0 \times 0.3 \mathrm{~cm}^{2}$ silicon PV cells (NaRec) using a piece of Scotch tape and the plate exposed to light from AM 1.5 spectrum from a $100 \mathrm{~mW} / \mathrm{cm}^{2}$ solar simulator (SolarConstant 1200 , K. H. Steuernagel Lichttechnik) and monitored by a digital output device. The ambient temperature of the air in the room was measured to be $21.5^{\circ} \mathrm{C}$ and the steady state temperature of the air under the simulator was measured to be $34.5^{\circ} \mathrm{C}$.

The (poly)carbonate lightguides were initially supported on two PMMA plates standing on edge so the sample would not touch the metallic laboratory bench surface and were approximately uniformly exposed to light from the K. H. Steuernagel Lichttechnik solar simulator. Thermal images of the surfaces of the three plate types were recorded with an FLIR T450 sc thermal camera set to emissivity 0.9 to match PMMA (Fluke). We estimate given variations of the plates an error in temperature $<5 \%$.

The $60 \times 40 \times 2 \mathrm{~cm}^{3}$ PMMA plate was also exposed to a $5 \times 5 \mathrm{~cm}^{2}$ area of light from a $300 \mathrm{~W}$ solar simulator fitted with filters to approximate the global AM 1.5 spectrum (Lot-Oriel) and surface temperature recorded using the device described previously. A second PMMA plate was assembled into an LSC module with top and bottom PV cells, supplied and mounted after analysis by Dutch Space B.V. (see Fig. 2 for a photograph of the prototype). The surface temperatures of the prototype exposed to environmental conditions outdoors were recorded by the thermal camera over a period of $1 / 2$ hour exposure.

Non-doped $10.0 \times 10.0 \times 1.0 \mathrm{~cm}^{3}$ cast PMMA plates (Plano Plastics) were used in additional heating studies. Multicrystalline PV cells (NaRec) were first sanded down to the surface of the silicon to remove the metal layer and the cell face attached to the edges of two PMMA plates using either a 'superglue' (Bison Seconde Lijm) or by a silicone-based adhesive (Pattex Repair Extreme). A $20 \mathrm{~mm}$, gauge factor 2.12 and temperature compensated to $11 \times 10^{-6} /{ }^{\circ} \mathrm{C}$ $120 \Omega$ PFL-20-11 strain gauge (Tokyo Sokki Kenkyujo Co. Ltd.) was glued to the rear surface of the photovoltaic using a $\mathrm{CN}$ adhesive (Tokyo Sokki Kenkyujo Co. Ltd) and connected to an MGCplus system equipped with an 8 channel AP815i transducer, using a 4 lead wire configuration so the electrical resistance measured is not affected by the temperature of the lead wires. The strain gauge was

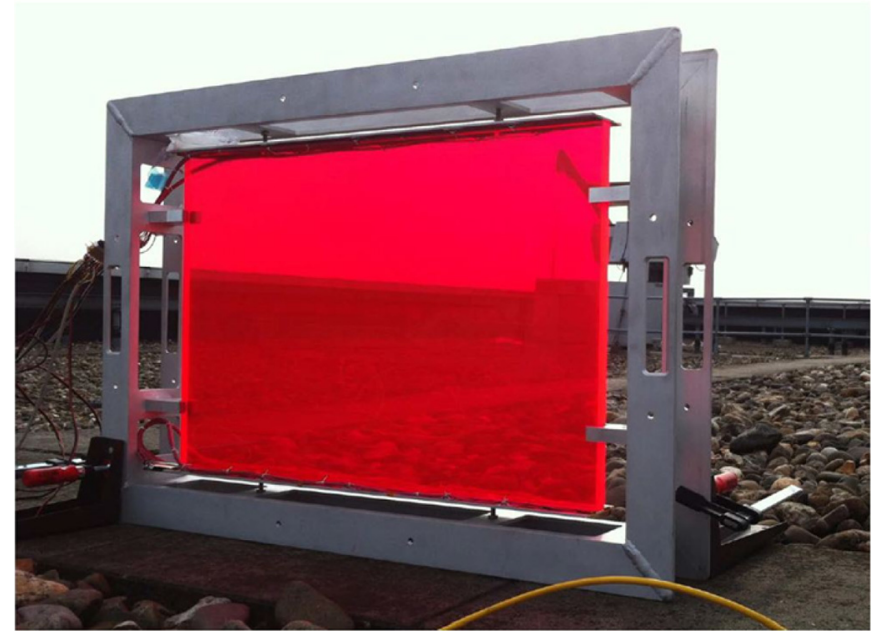

Fig. 2. Photograph of the larger prototype module using a PMMA plate filled with Red 305 dye on the roof of one of the buildings at the Eindhoven University of Technology used for the outdoor measurements of Section 3.2. 
measured in a full bridge configuration. The absolute strain $\left(\varepsilon_{\mathrm{Abs}}\right)$ of the specimen caused by the expansion of the polymeric plate placed in a temperature controlled oven and heated at a rate of $0.29^{\circ} \mathrm{C} / \mathrm{min}$ to $60^{\circ} \mathrm{C}$ followed by cooling to room temperature (RT), was determined by measuring the apparent strain $\left(\varepsilon_{\mathrm{App}}\right)$ and correcting for the thermal expansion coefficient $\left(\alpha_{\mathrm{SG}}\right)$ and the thermal output of the attached strain gauge $\left(\varepsilon_{\text {ref }}^{*}\right)$.

The absolute strain of the sample was calculated using the following formula.

$\varepsilon_{\mathrm{Abs}}(T)=\left(\varepsilon_{\mathrm{App}}(T)-\varepsilon_{\mathrm{ref}}^{*}(T)\right)+\alpha_{\mathrm{SG}} * \Delta T$

where $\varepsilon_{\text {app }}$ and $\varepsilon_{\text {ref }}^{*}$ are the measured strain of the specimen and the thermal output of the reference strain gauge and $\alpha_{\mathrm{SG}}$ the linear thermal expansion coefficient of the strain gauge. $\varepsilon_{\mathrm{Abs}}$ is the absolute strain of the specimen.

\section{Results}

\subsection{Polymeric lightguide temperatures}

First, three different plates were exposed to light from a solar simulator and a thermal camera was used to take images of the lightguide over time. The three plates were made of (poly)carbonate and were all the same size, $17.5 \times 17.5 \times 0.6 \mathrm{~cm}^{3}$. Two of the plates contained fluorescent dyes: one with Red 305 , a very common dye for LSC studies due to its high photostability, spectral coverage and fluorescent quantum yield [20], and the other a perylene perinone with some similar features [22]. The absorption spectra of the three plates are shown in Fig. 3.

The samples were placed horizontally on an insulating support under a solar simulator and the surface thermal images recorded at regular time intervals. The result of these experiments is shown in Fig. $4 a-c$.

All three plates displayed the same general heating trend, with the center of the plate heating the most rapidly and the outer parts heating more gradually. The Red 305 plate (Fig. 4b) apparently contained a defect of some type that resulted in a 'hot spot' on the spot left of the center of the plate. Fig. 5 depicts the temperature measured at the spot indicated by the small cross in the images as a function of illumination time.

The general heating trend for the three samples matches well to the measured absorbance spectra of the three plates depicted in Fig. 3. The clear (poly)carbonate has almost no absorption in the

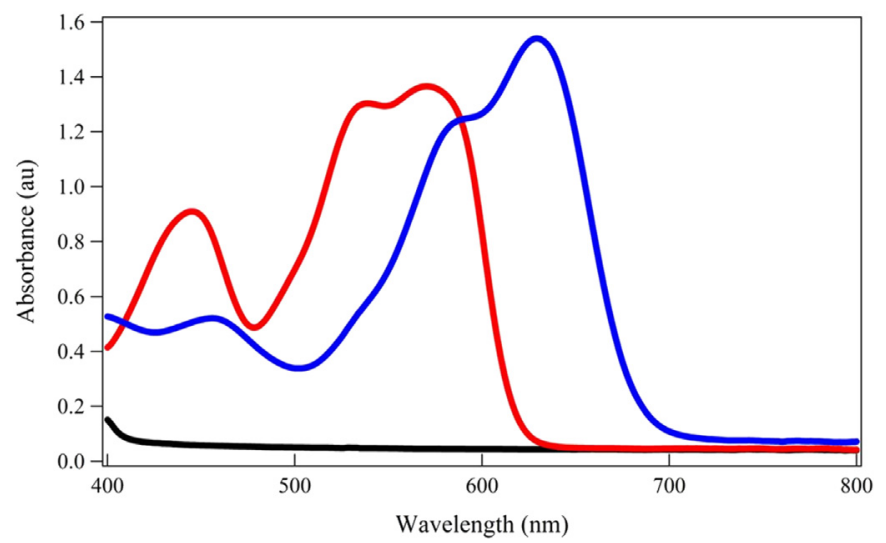

Fig. 3. Absorbance spectra of $17.5 \times 17.5 \times 0.6 \mathrm{~cm}^{3}$ (poly)carbonate plates containing no dye (black), Red 305 (red), and a perylene perinone (blue). (For interpretation of the references to color in this figure legend, the reader is referred to the web version of this article.) visible range, and only absorbs in the infrared beyond $1500 \mathrm{~nm}$ (see Fig. 6). This IR absorption, then, is primarily responsible for the heat increase of all the lightguides. The peaks at higher wavelengths are characteristic of the organic molecules making up the lightguide, and cannot be easily avoided. The Red 305 plate has the same absorbance as the blank plate, plus the additional light energy absorbed in the visible wavelength region. Finally, the perylene perinone has a broader absorption band than the Red 305 sample in the visible spectrum, and thus attains an even higher temperature when exposed to the simulated sunlight.

In practice, there may be conditions where only a fraction of the total area of the LSC will be illuminated. For example, shading by a tree or other masking structure may generate a 'hot' spot on the LSC surface, a region that experiences more intense illumination, while the rest of the plate remains under a lower illumination state. To study the effect and the resulting heat flows from this 'hotspot', a $60 \times 40 \times 2 \mathrm{~cm}^{3}$ LSC PMMA plate with the Red 305 dye was placed under a solar simulator which illuminated only a $5 \mathrm{~cm} \times 5 \mathrm{~cm}^{2}$ area, mimicking a 'hotspot'. The plate was measured under the illuminating light over a period of $35 \mathrm{~min}$. The results of the measurements are shown in Fig. 7. There are two main points of note. The overall temperature of the unexposed plate actually decreased during the measurement: the plate was brought from a warmer environment outside the lab into the cooler lab space. Second, the heating of the plate by the lamp was confined to the immediate vicinity of the 'hot spot'. The hot spot temperature gradually increased to $41.6{ }^{\circ} \mathrm{C}$ after $60 \mathrm{~min}$ where it more or less attained a steady state. In this experiment, the edge of the LSC plate closest to the hot spot after an hour exposure measured $23{ }^{\circ} \mathrm{C}$, which was only $2.5^{\circ} \mathrm{C}$ higher than the ambient temperature of $20.5^{\circ} \mathrm{C}$.

\subsection{Photovoltaic cell temperatures in LSC setup}

We have made direct measurements of the temperatures reached by edge mounted PV cells, and compared these temperatures to temperatures recorded on cells facing the illumination attached to the top and bottom of the lightguide. To do this, we attached a thermocouple to the front, rear, and side of the PV cell and measured temperature increases upon exposing the LSC device to light from a solar simulator. The results of these measurements are shown in Fig. 8.

The cell mounted to the top of the lightguide and facing the simulator reached its highest temperature after $18 \mathrm{~min}$ of exposure. The cell facing the simulator but located at the bottom of the Red 305 filled plate ran a few degrees cooler. However, the edge mounted PV cell was cooler by at least $5^{\circ}$ to the bottom mounted and a full $10^{\circ}$ cooler than the top mounted cell. While the setup of the top mounted cell is not directly equivalent to a functional PV panel (for example, it misses the glass cover sheet), it could be assumed that the temperature of a working model PV would be comparable to the values we describe here. If this $10{ }^{\circ} \mathrm{C}$ difference is consistent with devices working in the field, this could translate into the silicon PV cells performing $\sim 5 \%$ more efficiently when attached to the lightguide edge due to the cooler running conditions.

A $60 \times 40 \times 2 \mathrm{~cm}^{3}$ Red 305 plate mounted in an aluminum frame was taken outside to a grassy lawn on the TU Eindhoven campus on the 4th of September 2013 at 12:00, and placed facing southeast towards the sunlight and kept there for 50 min. It was a clear sunny day with a maximum temperature of $25{ }^{\circ} \mathrm{C}$. For the first $25 \mathrm{~min}$ pictures were taken every minute and after that the pictures were captured every $5 \mathrm{~min}$ and are shown in Fig. 9. The temperature was recorded from behind the prototype (the front of the prototype faced the sun) to avoid casting a shadow on the device while taking measurements. The steady state temperature behind the prototype was recorded at $32{ }^{\circ} \mathrm{C}$ after $50 \mathrm{~min}$. 
a
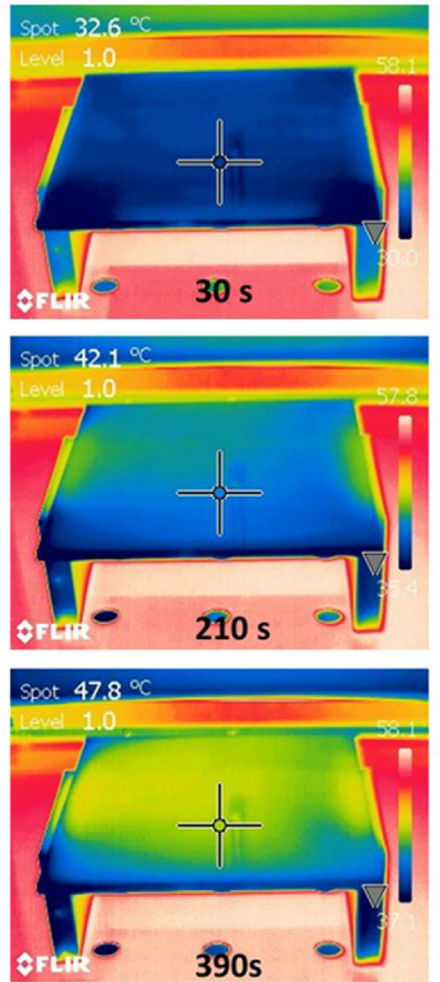

b
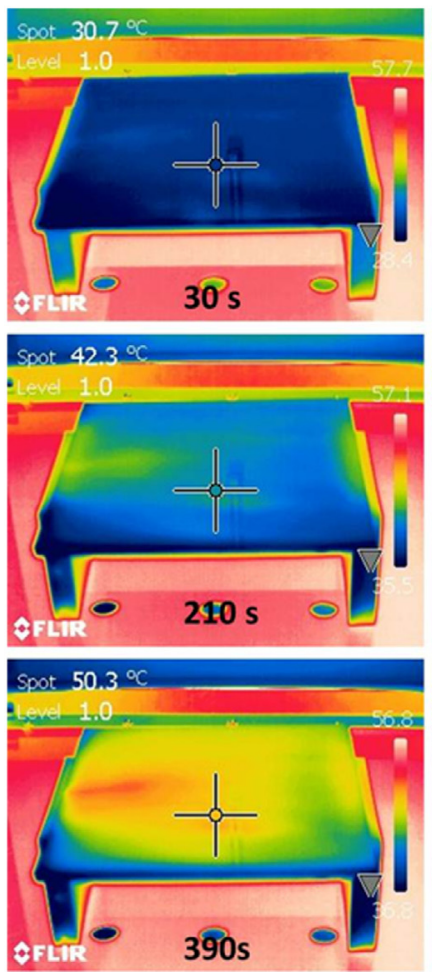
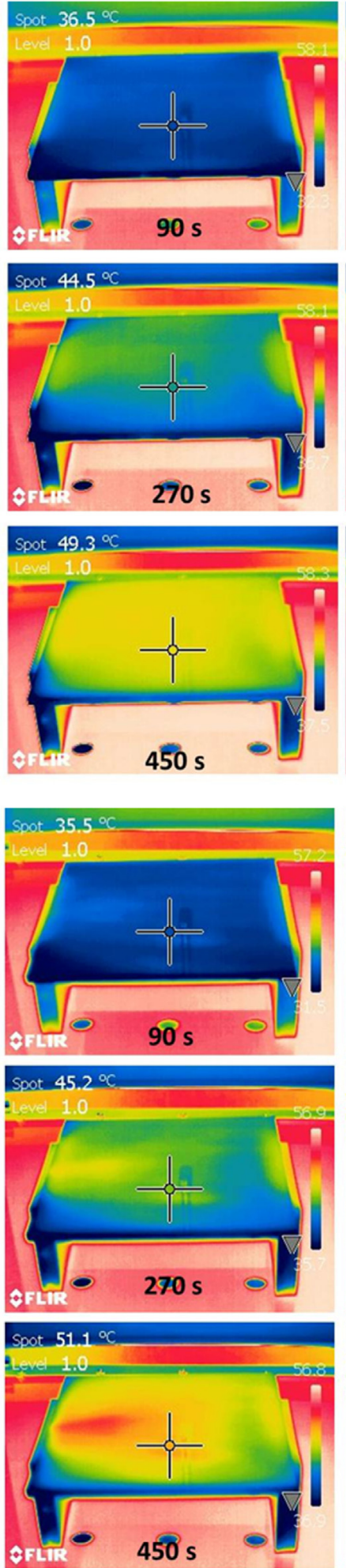
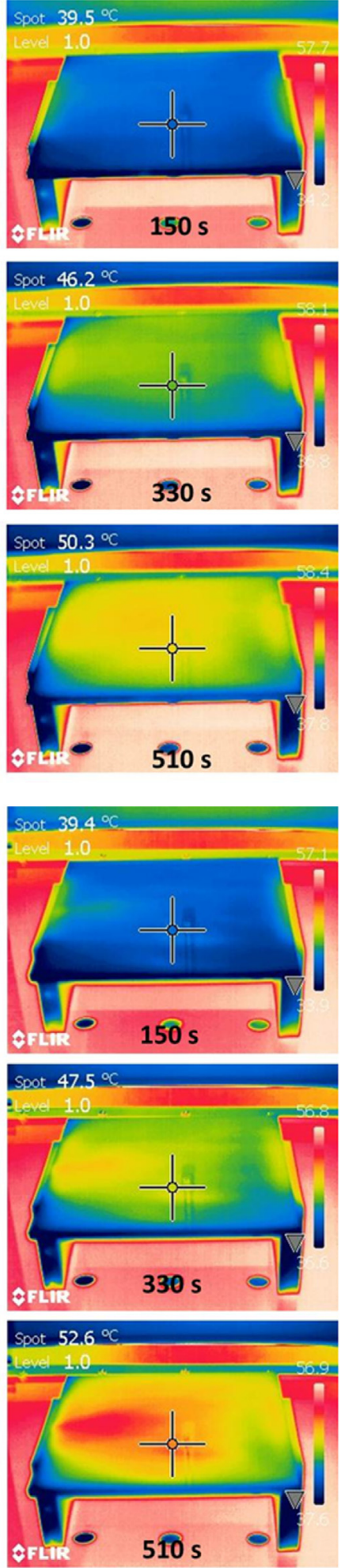

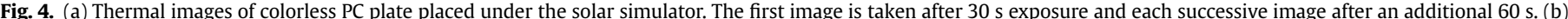

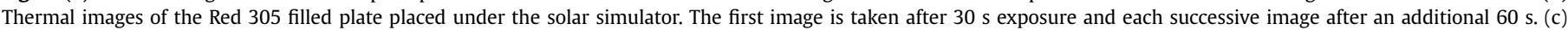

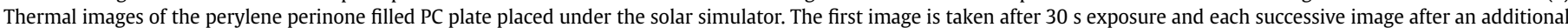
$60 \mathrm{~s}$.

The temperatures recorded at the point depicted by the cross in Fig. 9 are shown in Fig. 10. The device heats up over a period of approximately $30 \mathrm{~min}$ before reaching a generally steady state temperature several degrees above the nominal ambient temperature.

\subsection{Effect of gluing the PV cells}

One concern of attaching PV cells to the edges of the LSC lightguide is the danger of rupturing the cell upon heating the device, as the thermal expansion of the polymeric plates (generally 

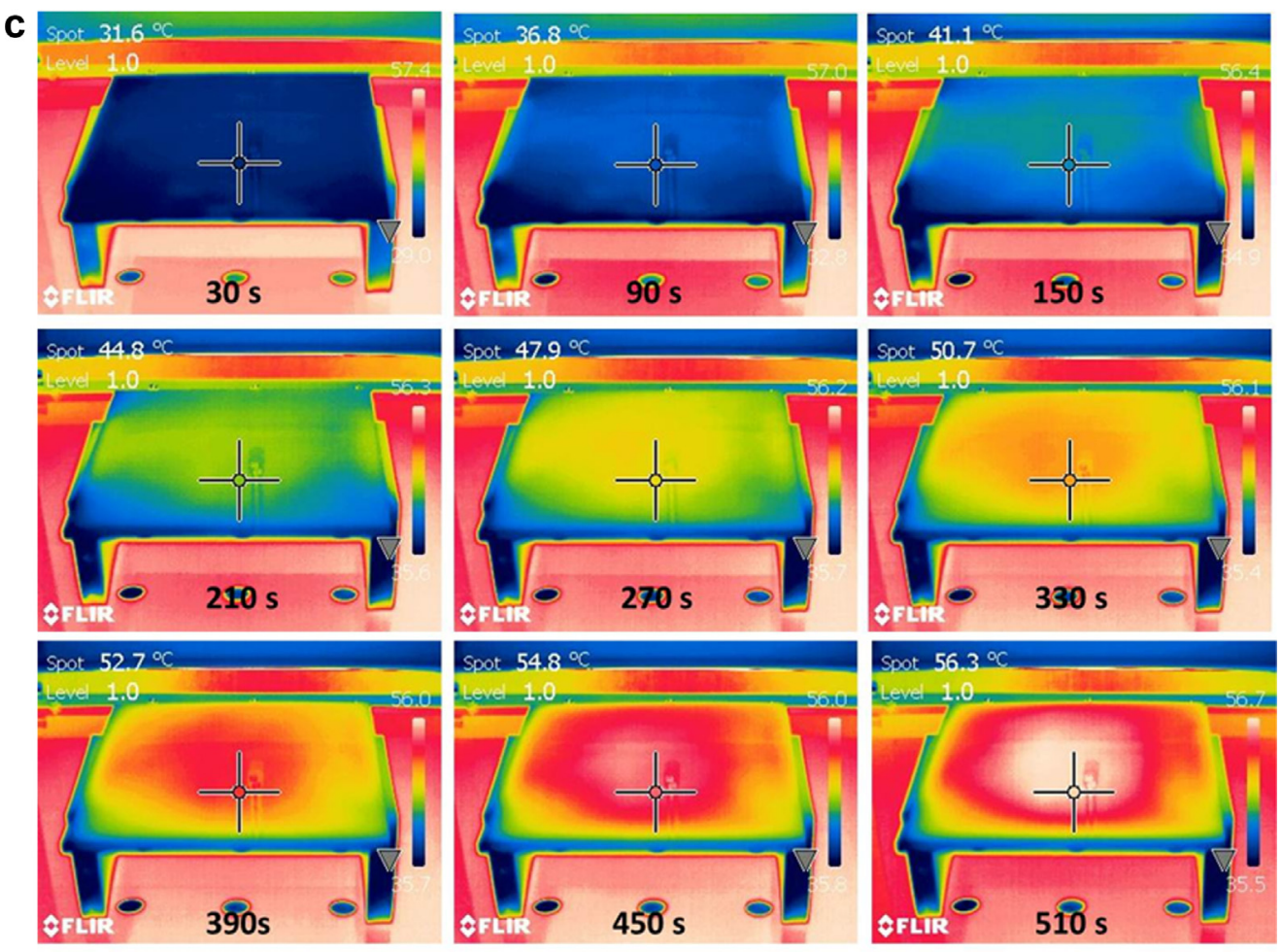

Fig. 4. (continued).

(poly)carbonate or PMMA) $[23,24]$ is many times greater than that of the silicon-based cells [25] or metal supports of the cells.

Any glue must not only withstand the stresses inherent in the differing coefficients of thermal expansion of the polymer plate and attached cell, but must do so for an extended period of time, and survive repeated heating/cooling cycles. We performed experiments to investigate the potential of various glues to be used in conjunction with the PVs and polymer lightguides.

First, two PV cells from the same industrial source were attached to the edges of a $10 \times 10 \times 1 \mathrm{~cm}^{3}$ PMMA plate. One was attached using a fast-set so-called 'superglue', and the other by a siliconebased adhesive. Thermal strain gauges were attached to each cell, as well as the top surface of the PMMA plate. The samples were

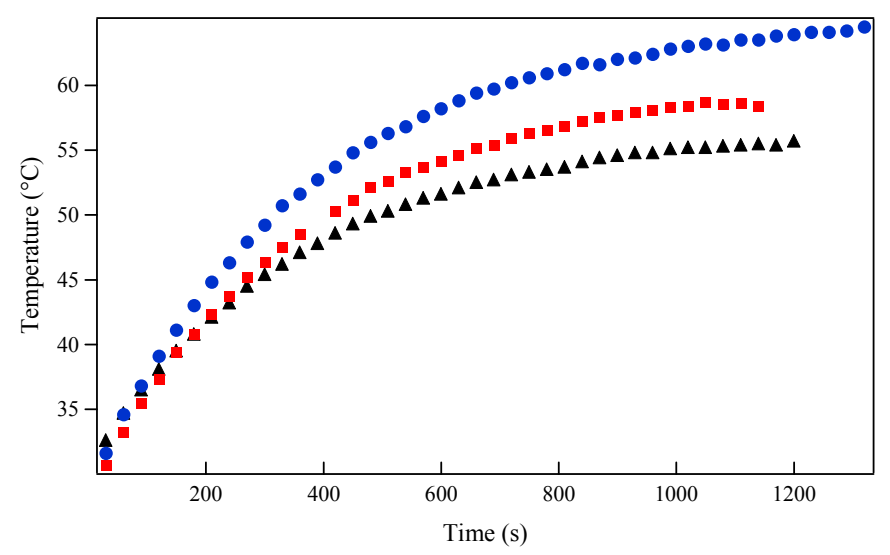

Fig. 5. Estimated spot temperature as a function of time after exposure to a solar simulator determined at the intersection of the crosses seen in the images of Fig. $4 \mathrm{a}-\mathrm{c}$. The individual samples are a clear (poly)carbonate plate (black), the same grade (poly) carbonate containing the perylene perinone (blue), and Red 305 (red). (For interpretation of the references to color in this figure legend, the reader is referred to the web version of this article.) placed in a temperature controlled oven and allowed to heat from room temperature to $60{ }^{\circ} \mathrm{C}$ at $0.29{ }^{\circ} \mathrm{C} / \mathrm{min}$ and returned to room temperature overnight. The strain on the PV cells by the expanding PMMA plate was recorded, and is depicted in Fig. 11. Assuming the materials were homogeneous and expanded isotropically, we used a linear fit of the data to determine the linear coefficient of thermal expansion

$\alpha_{L}=(\Delta L / L)(1 / \Delta T)$

From the initial slopes of the lines in Fig. 11, we determined $82 \times 10^{-6}{ }^{\circ} \mathrm{C}^{-1}$ for the PMMA and $2.5 \times 10^{-6}{ }^{\circ} \mathrm{C}^{-1}$ for the PV cell, consistent with previous results $[23,25]$.

Visual inspection of the samples after the temperature cycling was completed showed the cell attached by the super glue had cracked in two places. The first event occurred soon after the start of the process: the point of initial damage being indicated by the

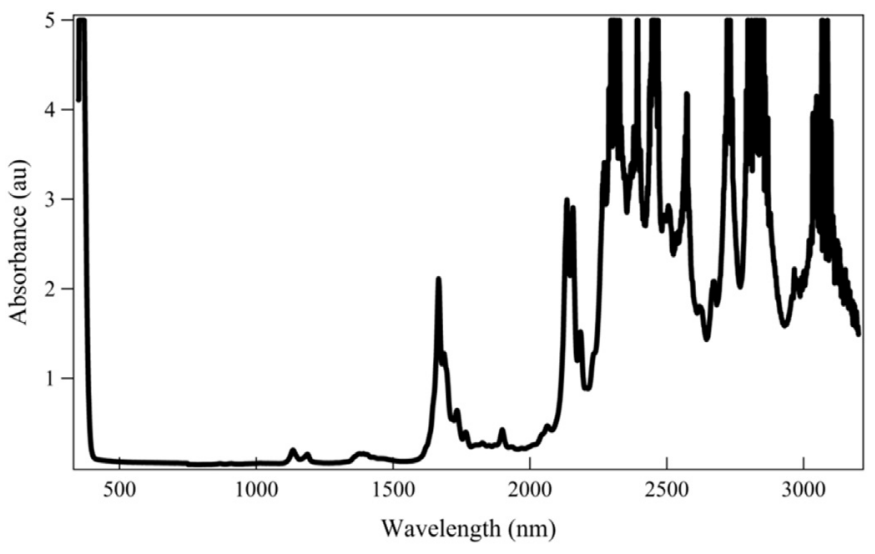

Fig. 6. Extended absorbance spectrum of blank (poly)carbonate sample. 

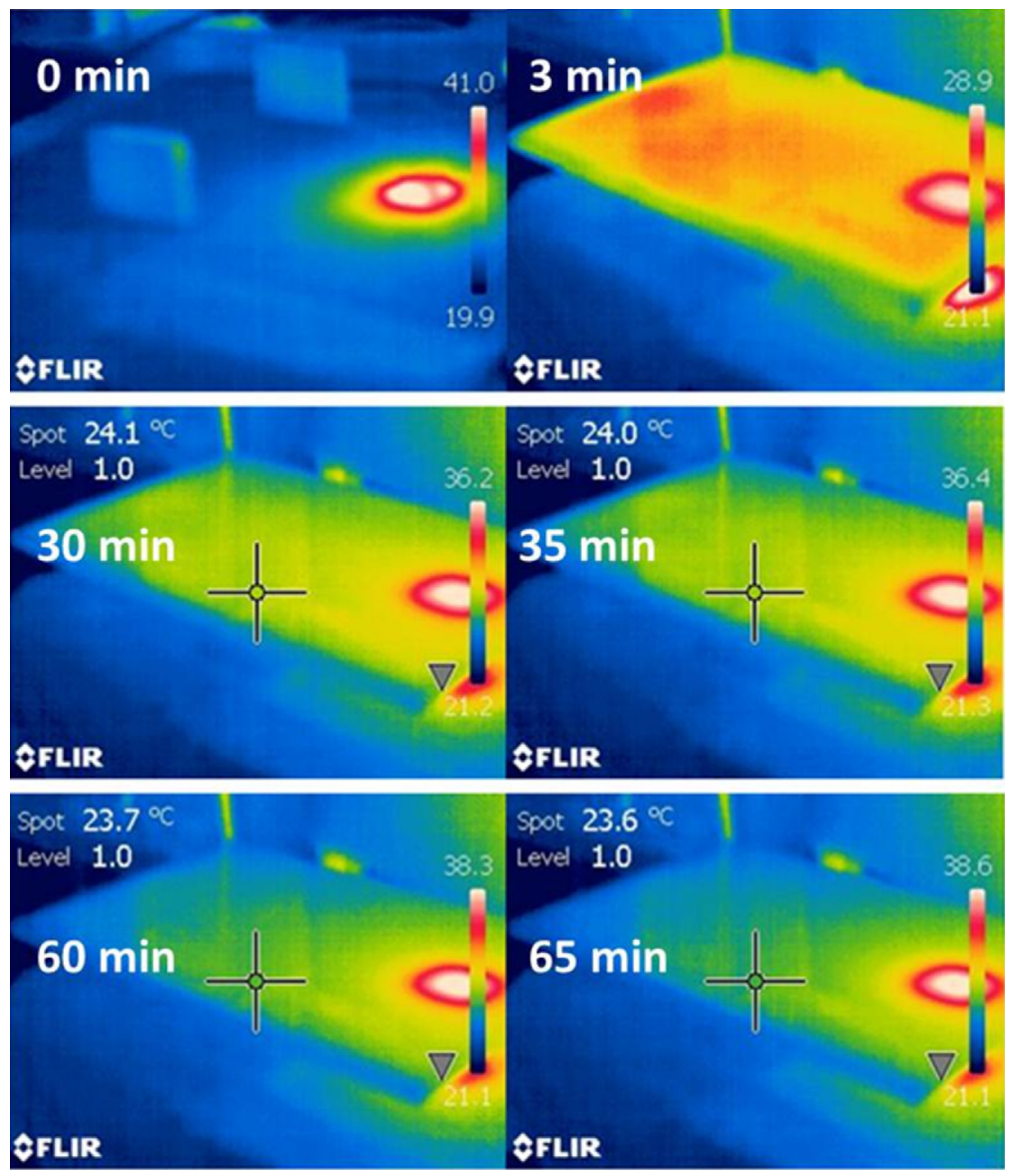

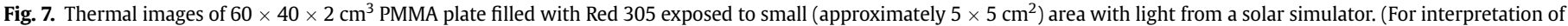
the references to color in this figure legend, the reader is referred to the web version of this article.)

black arrow in Fig. 11. A second crack was recorded, and shown by the gray arrow in the same figure. Initially, there was a monotonic increase in strain in the cell, but after the initial damage, the gauge on the cell showed a response similar to that of the PMMA plate

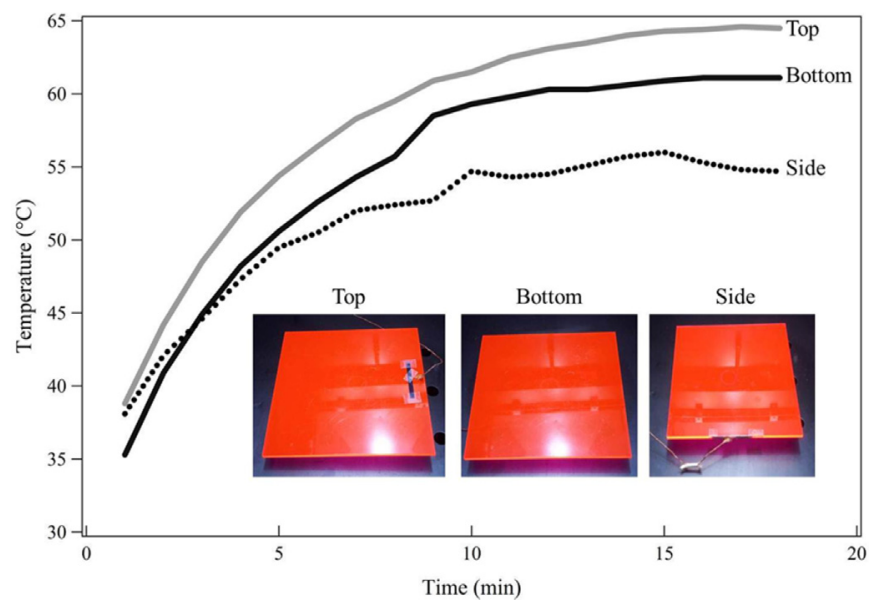

Fig. 8. Measured cell temperature as a function of exposure time to light from a solar simulator for a cell located on top of the PMMA plate facing the simulator (gray solid line), on the bottom of the PMMA plate facing the simulator (black solid line) and on an edge of the plate (black dotted line). Inset: Photos of plates with cells attached at the front (left), bottom (middle) and side (right). itself. The second, silicone-based glue was much more pliant, and limited the strain experienced by the attached cell. The cell was seen to be whole upon visual inspection, and the optical attachment to the lightguide was likewise maintained. Fig. 12 is a more expanded view of the experiment shown in Fig. 11. The samples were cycles from room temperature to $60,70,60,70$, and $80^{\circ} \mathrm{C}$ over a span of $20 \mathrm{~h}$. The rupture and subsequent second cracking of the PV attached by the rigid glue (red lines) are clearly visible in Fig. 11 within the first $2 \mathrm{~h}$ of the first heating run. After breakage, the expansion and contraction followed the course of the bare PMMA (blue line) very closely. From this graph, it is also clear that the cell attached via the silicone glue (green line) experienced lower strain and cycled well for the duration of the experiment. Thus, it is clear that the glue composition will be critical to the introduction of the LSC to the built environment. Considerably more research must be performed in this area before the LSC may become a common device for urban integration.

\section{Discussion}

The luminescent concentrator is being considered for use in the built environment. However, before successful deployment, a number of performance parameters must be better understood for the device. One aspect that has not been adequately studies is the thermal performance of the LSC. It has always been implicitly assumed that a PV cell attached to the edge of an LSC device should 

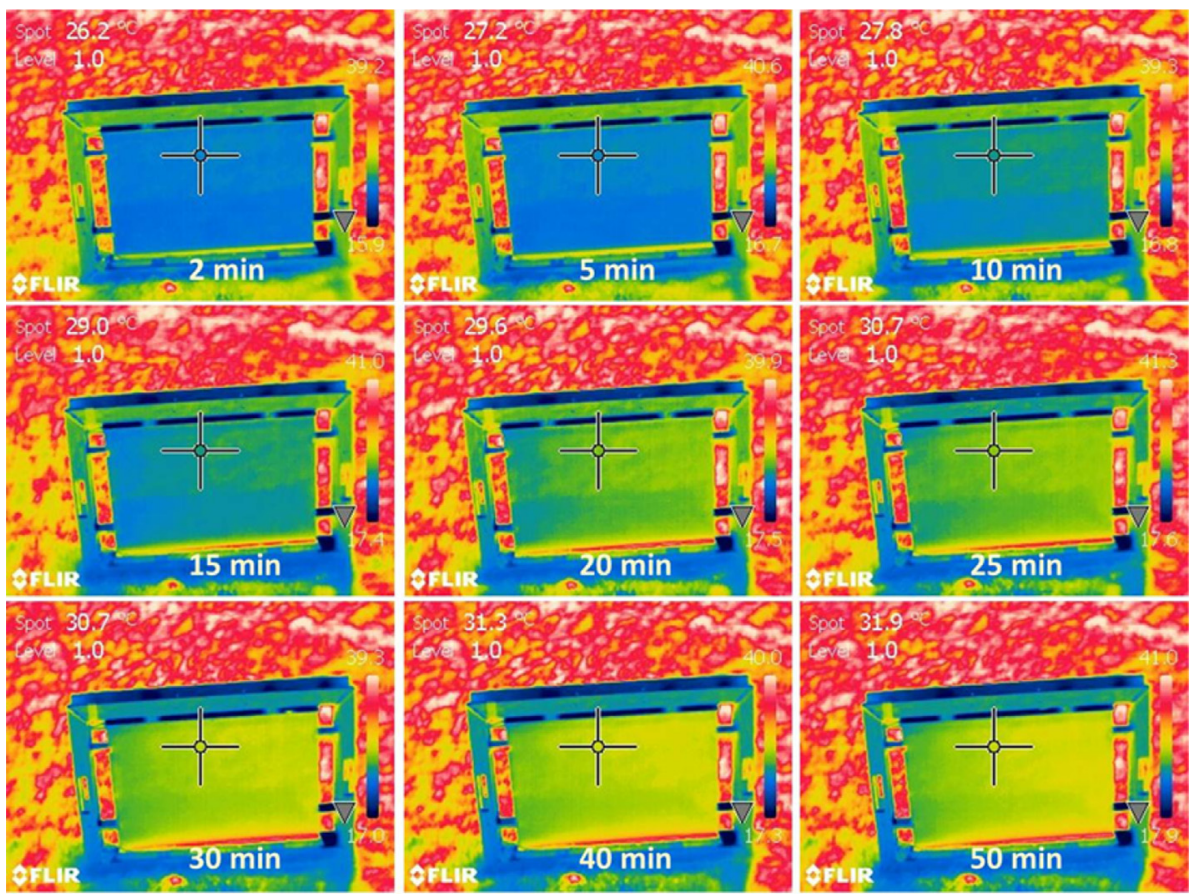

Fig. 9. Outside testing heat flows (measured from behind the plate).

run cooler than a similar cell exposed directly to the sun, but this has never been experimentally demonstrated. Additionally, it has always been assumed that the PV cell will eventually be attached to the lightguide edge via an adhesive. What has not been sufficiently detailed is the effect of thermal expansion and contraction on the integrity of the attached cell. These are the two aspects of the device that we wished to ascertain in this work.

Since the materials of the LSC do not absorb all incident light, this means a significant fraction of light that would not be used by the PV cell to generate electricity but would only serve to raise the temperature of the PV simply passes through the polymer lightguide. The light that is collected by the embedded dyes is itself downshifted in energy, the final energies being closer to the bandgap of the PV cell than the incident light, leaving even less energy available for heating the cell. The results of the thermal measurements of Section 3.1 suggest that the edge attached PV cells will run cooler on LSCs than they would were they exposed to direct sunlight. Much of the cell heating in standard PV panels is

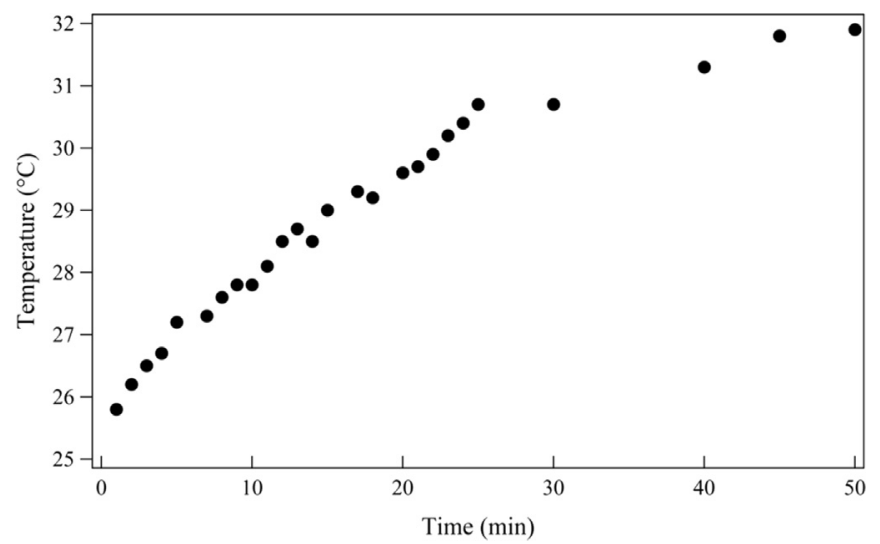

Fig. 10. Temperature of prototype module placed outdoors on September 4, 2013, determined from the infrared camera as a function of exposure time. the panel's absorption of incident light beyond light usable for charge pair generation. In the LSC, the light incident on the PV will only correspond to the emission wavelengths emitted by the fluorescent dye and the absence of infrared light. If the PV cells do function at a lower temperature, they could then perform at a peak efficiency. The thermal photos in Fig. 3 suggest that the edges of the lightguides do not attain the temperatures of the bulk of the device. The thermal images taken of the polymeric plates in Fig. 7 show that locally, temperatures in the plates increase, but that this heat is not readily transferred to the lightguide edge. When PV cells are pressed to the edges of the lightguide, they ran up to $10^{\circ} \mathrm{C}$ cooler

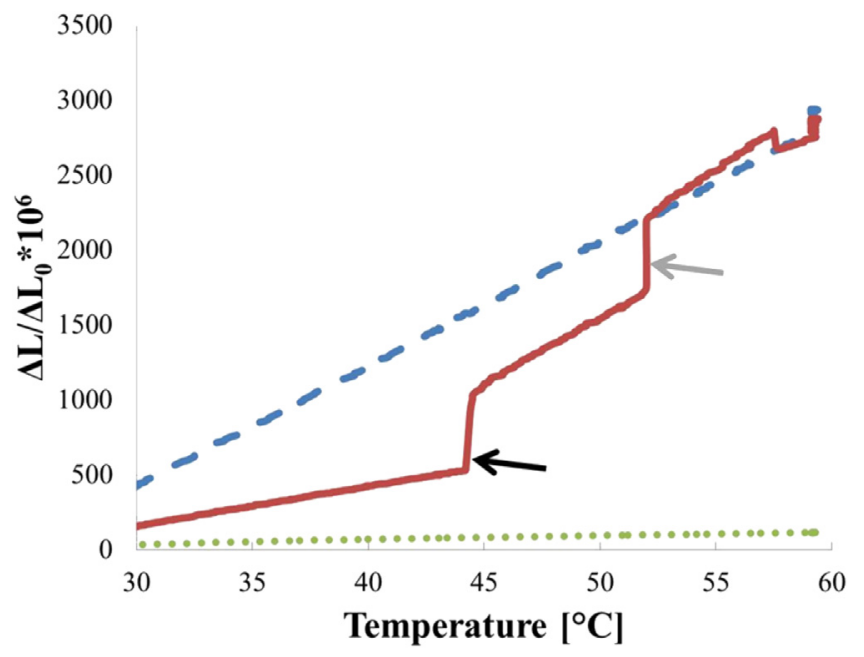

Fig. 11. Plot of strain as a function of temperature for PMMA plate (dashed blue line) and for PV cells attached to the lightguide edge by superglue (solid red line) and silicone based adhesive (dotted green line). The black arrow indicates the initial cell breakage event, and the gray arrow the second cell breakage event. (For interpretation of the references to color in this figure legend, the reader is referred to the web version of this article.) 


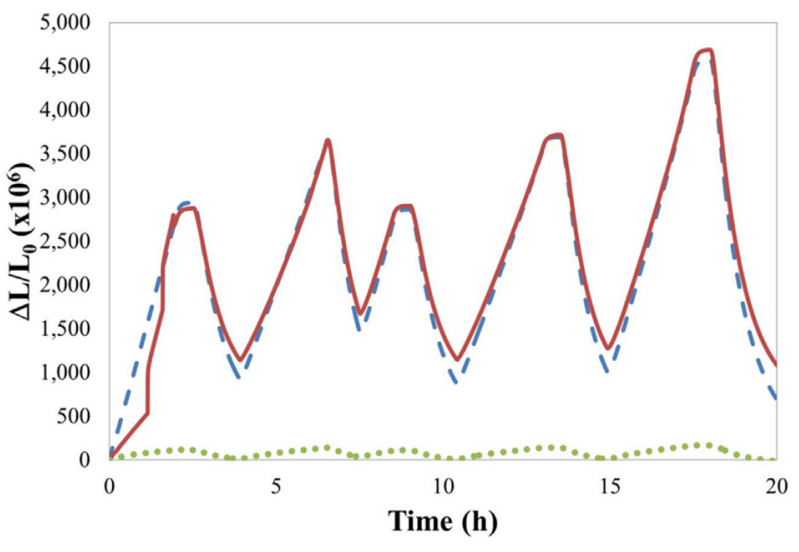

Fig. 12. Plot of microstrain as a function of time for PMMA plate (dashed blue line) and for PV cells attached to the lightguide edge by superglue (solid red line) and silicone based adhesive (dotted green line). The peaks represent heating ramps terminating at $60,70,60,70$, and $80^{\circ} \mathrm{C}$. (For interpretation of the references to color in this figure legend, the reader is referred to the web version of this article.)

than PV cells paced so as to directly face the light source, as shown in Section 3.2. This temperature difference is significant: it suggests a PV cell in an LSC configuration could run significantly cooler than when used in the traditional manner, which is directly facing the sun. This could result in the LSC demonstrating less performance degradation under bright, sunny conditions. Given the findings of this work which shows downshifting of sunlight energies to longer wavelengths which will encounter the PV cell over a narrow bandwidths can reduce cell heating, it would be interesting to develop a simulation method capable of predicting the temperature variations of the cells as a function of incorporated fluorescent dye spectra and lightguide polymeric identity.

Finally, the obvious difference in the coefficient of thermal expansion (CTE) between the polymeric plates and a silicon solar cells demands attention from a device design perspective. As shown in Section 3.3, the choice of adhesive to attach the PV cell to the polymer lightguide, essential in maintaining good optical contact and ensuring the light from the lightguide enters the PV cell, is vital as it needs to mediate between two materials with such differing CTEs. While this has only been a first step in identifying the optimal glue, it is apparent that a stiff adhesive can result in cracking and destruction of the attached cell. For outdoor use, of course, much more work must be done in this area as not only do thermal changes need to be considered, but also the adhesive must be resistant to moisture and other damaging elements common to long-term outdoor applications as well.

\section{Conclusions}

We have presented a study on the heating of a series of PMMA and (poly)carbonate lightguides containing fluorescent dyes acting as luminescent solar concentrators in order to determine the effects of light exposure on the temperature of mounted photovoltaic cells. We have shown that polymeric plates containing fluorescent dye molecules reach higher temperatures than non-doped plates. However, we have demonstrated that photovoltaic cells attached to the side of an LSC lightguide operate at a lower temperature than when placed on top or below the plate directly facing the sun (up tp $10^{\circ} \mathrm{C}$ ), suggesting that the cells on the edge of an LSC will run cooler than a PV cell facing the sun and that the performance of the LSC will not degrade due to PV cell heating. Initial studies of cell attachment have clearly shown that the choice of glue is vital in handling the mismatch between the thermal expansion of the polymer plates and the photovoltaic cell, and this latter research will become very important if the LSC device is to be successfully commercialized.

\section{References}

[1] Weber WH, Lambe J. Luminescent greenhouse collector for solar radiation. Appl Opt 1976;15:2299-300.

[2] van Sark WGJHM, Barnham KWJ, Slooff LH, Chatten AJ, Büchtemann A Meyer A, et al. Luminescent solar concentrators - a review of recent results. Opt Express 2008;16:21773-92.

[3] Debije MG, Verbunt PPC. Thirty years of luminescent solar concentrator research: solar energy for the built environment. Adv Energy Mater 2012;2: $12-35$.

[4] Kerrouche A, Hardy DA, Ross D, Richards BS. Luminescent solar concentrators: from experimental validation of 3D ray-tracing simulations to coloured stained-glass windows for BIPV. Sol Energy Mater Sol Cells 2014;122:99-106.

[5] Slooff LH, Bende EE, Burgers AR, Budel T, Pravettoni M, Kenny RP, et al. A luminescent solar concentrator with $7.1 \%$ power conversion efficiency. Phys Status Solidi - R 2008;2:257-9.

[6] Goldschmidt JC, Peters M, Bösch A, Helmers H, Dimroth F, Glunz SW, et al. Increasing the efficiency of fluorescent concentrator systems. Sol Energy Mater Sol Cells 2009;93:176-82.

[7] Desmet L, Ras AJM, De Boer DKG, Debije MG. Monocrystalline silicon photovoltaic luminescent solar concentrator with $4.2 \%$ power conversion efficiency. Opt Lett 2012;37:3087-9.

[8] Cellura M, Di Gangi A, Longo S, Orioli A. Photovoltaic electricity scenario analysis in urban contests: an Italian case study. Renew Sustain Energy Rev 2012; 16:2041-52.

[9] Petter Jelle B, Breivik C, Drolsum Røkenes H. Building integrated photovoltaic products: a state-of-the-art review and future research opportunities. Sol Energy Mater Sol Cells 2012;100:69-96.

[10] Gray JL. Handbook of photovoltaic science and engineering. Hoboken, USA: Wiley; 2007.

[11] Davis MW, Fanney AH, Dougherty BP. Prediction of building integrated photovoltaic cell temperatures. J Sol Energy Eng 2001;123:200-10.

[12] Skoplaki E, Palyvos JA. On the temperature dependence of photovoltaic module electrical performance: a review of efficiency/power correlations. Sol Energy 2009;83:614-24.

[13] Fesharaki VJ, Dehghani M, Fesharaki JJ, Tavasoli H. The effect of temperature on photovoltaic cell efficiency. In: Proceedings of the 1st international conference on emerging trends in energy conservation, Tehran, Iran; 2011. p. 6.

[14] Raga SR, Fabregat-Santiago F. Temperature effects in dye-sensitized solar cells. Phys Chem Chem Phys 2013;15:2328-36.

[15] Mohring H-D, Stellbogen D. Annual energy harvests of PV systems - advantages and drawbacks of different PV technologies. In: 23rd European photovoltaics solar energy conference, Valencia, Spain; 2008. p. 2781-5.

[16] Emery K, Burdick J, Caiyem Y, Dunlavy D, Field H, Kroposki B, et al. Temperature dependence of photovoltaic cells, modules and systems. In: Proceedings of the 25th IEEE PV specialists conference, Washington DC, USA; 1996. p. $1275-8$.

[17] Du D, Darkwa J, Kokogiannakis G. Thermal management systems for photovoltaics (PV) installations: a critical review. Sol Energy 2013;97:238-54.

[18] Kurtz S, Miller D, Kempe M, Bosco N, Whitefield K, Wohlgemuth J, et al. Evaluation of high-temperature exposure of photovoltaic modules. In: 34th IEEE photovoltaic specialists conference, Philadelphia, USA; 2009.

[19] Amin N, Lung CW, Sopian K. A practical field study of various solar cells on their performance in Malaysia. Renew Energy 2009;34:1939-46.

[20] Wilson LR, Richards BS. Measurement method for photoluminescent quantum yields of fluorescent organic dyes in polymethyl methacrylate for luminescent solar concentrators. Appl Opt 2009;48:212-20.

[21] Seybold G, Wagenblast G. New perylene and violanthrone dyestuffs for fluorescent collectors. Dyes Pigm 1989;11:303-17.

[22] Debije MG, Verbunt PPC, Nadkarni PJ, Velate S, Bhaumik K, Nedumbamana S, et al. Promising fluorescent dye for solar energy conversion based on a perylene perinone. Appl Opt 2011;50:163-9.

[23] Harper CA. Handbook of plastics and elastomers. New York, USA: McGrawHill: 1975.

[24] Goods SH, Watson RM, Yi M. Thermal expansion and hydration behavior of PMMA molding materials for LIGA applications. Albuquerque, New Mexico: Sandia Corporation; 2003. p. 57.

[25] Wirth H. Crystalline silicon PV module technology. In: Advanced in semiconductors, part 2: semiconductors and semimetals. Amsterdam, The Netherlands: Elsevier; 2013. p. 135-94. 